\title{
Association of rotating night shift with lipid profile among nurses in an Egyptian tertiary university hospital
}

Mohsen Gadallah', Sally A. Hakim ', Amira Mohsen ${ }^{2}$ and Waleed S. Eldin ${ }^{7}$

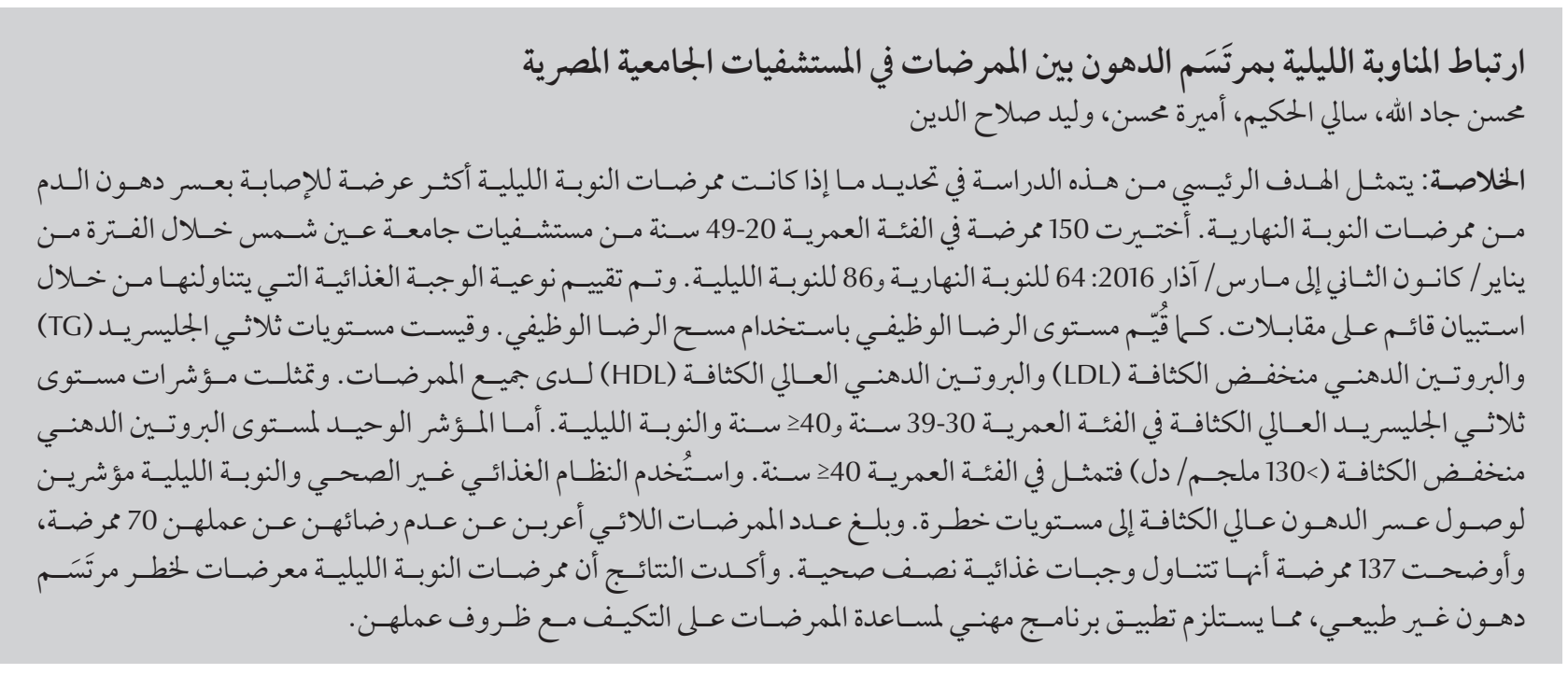

ABSTRACT The main objective was to identify whether night shift nurses are more prone to dyslipidaemia than day shift nurses. One hundred and fifty female nurses aged 20-49 years were recruited from Ain Shams University Hospitals, Egypt, from January to March 2016: 64 day shift and 86 night shift. Diet type was assessed by interview questionnaire and job satisfaction was assessed using the job satisfaction survey. Triglyceride (TG), low-density lipoprotein (LDL) and high-density lipoprotein (HDL) were measured in all nurses. The predictors of high TG level were ages 30-39 and $\geq 40$ years and night shift. The only predictor of high LDL level (>130 mg/dl) was age $\geq 40$ years. An unhealthy diet and night shift were predictors of risky HDL levels. Seventy nurses were unsatisfied with their jobs, and 137 ate a semi-healthy diet. The findings emphasize that night shift nurses are at risk of abnormal lipid profile, therefore an occupational programme to help nurses cope with their employment conditions is necessary.

\section{Association entre les rotations d'équipes de nuit et le profil lipidique d'infirmières d'un centre hospitalier universitaire de soins tertiaires en Égypte}

RÉSUMÉ L'objectifprincipal de la présente étude consistait à déterminer si les équipes de nuit d'infirmières sont davantage sujettes à la dyslipidémie que les équipes de jour. Cent cinquante infirmières âgées de 20 à 49 ans ont été recrutées dans le centre hospitalier universitaire d'Aïn Shams entre janvier et mars 2016, dont 64 travaillant dans des équipes de jour et 86 dans des équipes de nuit. Le régime alimentaire a été évalué dans un questionnaire d'entrevue, et une enquête sur la satisfaction au travail a été menée. Les triglycérides, les lipoprotéines de basse densité (LDL) et les lipoprotéines de haute densité (HDL) ont été mesurées chez toutes les infirmières. Un âge compris entre 30 et 39 ans, et supérieur ou égal à 40 ans, et le travail de nuit constituaient les facteurs prédictifs d'une élévation du taux de triglycérides. Être âgé de 40 ans ou plus était le seul facteur prédictif d’un niveau élevé de LDL (supérieur à $130 \mathrm{mg} / \mathrm{dl}$ ). Un régime alimentaire malsain et le travail en équipes de nuit constituaient des facteurs prédictifs de tauxà risque de HDL. Sept infirmières étaient insatisfaites de leur travail, et 137 avaient des régimes alimentaires partiellement sains. Les résultats mettent en évidence le fait que les infirmières qui travaillent en équipes de nuit ont un risque de présenter un profil lipidique anormal. Un programme de santé au travail est donc nécessaire pour aider les personnels infirmiers à faire face à leurs conditions de travail. 


\section{Introduction}

Over the past few decades there has been a rapid increase in the number of shift workers worldwide (1). Abnormal eating behaviour is associated with nursing shift work. Nurses are reported to eat more to cope with stress and more high-sugar foods in order to stay wakeful (2).

Diet is one of the most important determinants of human health. Proper eating habits and rationally balanced food ratios positively affect the human body, whereas poorly balanced diet coupled with improper nutritional habits may give rise to many diet-related diseases such as diabetes, cardiovascular diseases, hypertension, stroke and some types of cancer (3).

Nurses working night shifts or rotating shifts are noted to be at higher risk than their daytime co-workers, placing them at increased risk for compromised health and work ability (4). The response to the chronic stress perceived with these disruptions (shorter sleep time and rotatory night shift) involves release of hormones such as cortisol and adrenaline. The documented health risks attributed to elevated cortisol levels include dyslipidaemia, hypertension, obesity, noninsulin-dependent diabetes, and stroke (5). The resultant health concerns for shift workers include increased risks for colorectal cancer, breast cancer, chronic fatigue, anxiety, miscarriage, hypertension, obesity, diabetes and hypercholesterolaemia $(6,7)$.

As there is a scarcity of research in Egypt about the lipid profile among nurses working night shifts, the results of the present study may provide some clues about factors associated with abnormal lipid profiles among nurses. From a review of previous systematic analyses and meta-analyses, we expected an excess abnormal lipid profile among night shift compared to their day shift colleagues. Therefore, the main objectives of this work were to study the relationship between rotatory night shift and lipid profile and to identify factors associated with dyslipidaemia.

\section{Methods}

\section{Study population}

One hundred and fifty female nurses aged 20-49 years were recruited: 64 (42.7\%) were day shift workers (always working during the day) and 86 (57.3\%) were currently night shifters (working in a rotating system for $>1$ year). All nurses were affiliated to Ain Shams University Hospitals. All nurses working in Ain Shams University Hospitals are female; therefore, the study sample included only female nurses.

\section{Sample size}

Using the Epi-Info software with an expected percentage of dyslipidaemia among nurses working in rotating night shifts of $50 \%$ in comparison to $25 \%$ among day shift workers, with $95 \%$ confidence intervals and $80 \%$ test power, the sample size required was 132 with at least 66 participants in each group. To compensate for nonparticipation of nurses to join the study and the small number of nurses working in outpatient clinics, we decided to recruit a larger sample size and contact all eligible nurses. Almost all nurses working in the inpatient departments must work in a rotatory system, while nurses working in the outpatient clinics work only during the day. Accordingly, the study sample included nurses from inpatient departments and outpatient clinics. Exclusion criteria included: nurses with diseases or using medications that potentially affect lipid profile; or nurses who had changed from night shift to day shift within the past 12 months. The total number of nurses working in the night shift system during the study was 112; 14 of them were new to night shift working and they were excluded. Out of 98 eligible nurses working night shifts, 86 (87.8\%) agreed to participate. Eighty-five nurses worked only during daytime. Ten of them had a history of working in the evening or night shift in private hospitals and they were excluded. Therefore, the remaining 75 eligible nurses working in the daytime were contacted and $64(85.3 \%)$ agreed to join the study. The main reason behind refusal to participate was that the nurses did not have time to go to the laboratory for lipid profile analysis because it needed at least 12 hours fasting. Data were collected during January-March 2016.

\section{Dietary behaviour}

The type of dietary intake was assessed by interview questionnaire designed by the authors after intensive study of different questionnaires used for assessment of dietary behaviour. The questionnaire consisted of 18 questions that were mostly mentioned in previous behavioural questionnaires, including: average frequency per week of eating processed meat, red meat, chicken/ fish, lentils/beans, cheese and dairy products, bread/carbohydrate meals, vegetables, fruits, eggs, fast foods, snacks of vegetables and fruits, having breakfast, removing poultry or meat skin, and their usual dessert. Each question was given a score from 1 to 3 , with 3 considered to be healthy behaviour. The total expected score ranged between 18 and 54. The following classification was applied: unhealthy diet for those with score $\leq 27$; semi-healthy diet for those with score 28-41; and healthy diet for those with score $\geq 42$. All participating nurses scored $<42$. Therefore, participants were divided into 2 groups: one having a semi-healthy diet that needed some modifications; and the other with an unhealthy diet that needed many modifications. The questionnaire was first piloted on a sample of 20 nurses (10 each from inpatient departments and outpatient clinics). The reliability of this dietary questionnaire was 0.68 using Cronbach's $\alpha$. 


\section{Job satisfaction}

Job satisfaction was assessed using the job satisfaction survey of Paul E. Spector 1994 (all rights reserved (8). The questionnaire included items about: payment, promotion, supervisors, rules and procedures at work, colleagues, value of the job, being appreciated for the task you do, and having a sense of pride in doing your job. The answers were on a scale from disagreeing very much to agreeing very much. We used the 36item questionnaire for which possible scores ranged from 36 to 216; then the score was categorized into 36 to $<108$, dissatisfaction; 144-216, satisfaction; and 108-144, ambivalent (indecisive).

\section{Measurement of body mass index (BMI)}

All nurses were asked to remove their shoes before measuring body weight and height. BMI is defined as weight in kilograms divided by the square of the height in meters $\left(\mathrm{kg} / \mathrm{m}^{2}\right)$. The international classification of adult weight status according to $\mathrm{BMI}$ is: normal range, 18.5-24.9; overweight, 25.0-29.9; and obese, $\geq 30.0$.

\section{Physical activity}

We asked about frequency of exercise in the last 30 days: none, rarely/occasionally, regularly 1 or 2 times/week, and regular $\geq 3$ times/week. Those exercising regularly were asked about their exercise intensity; light (no/slight increase in heart rate and respiration, no sweating); moderate (noticeable increase in heart rate and respiration, some sweating); and heavy (fast heart rate, laboured respiration, obvious sweating). For statistical analysis, the first 2 categories were combined into 1 $=$ none $/$ rare. We classified nurses who exercised in a regular manner ( 1 or 2 times or $>2$ times) into 2 categories: light-intensity physical exercise and moderate intensity exercise. None of the nurses reported heavy exercise intensity. All 150 nurses who participated were asked to go to a designated laboratory where triglyceride (TG), low-density lipoprotein (LDL) and high-density lipoprotein (HDL) were measured after a 12-hour fast. The following abnormal values for lipoproteins were used: TG $>200 \mathrm{mg} / \mathrm{dl}, \mathrm{LDL}>130 \mathrm{mg} / \mathrm{dl}$ and HDL (risk) $<40 \mathrm{mg} / \mathrm{dl}$.

\section{Statistical analysis}

We used IBM-SPSS version 20 for statistical analysis. The $\chi^{2}$ test was used to compare categorical variables. Unadjusted odds ratio (OR) and 95\% confidence intervals (CIs) were used for all bivariate analysis. All variables that were significant in the bivariate analysis were tested further using a binary logistic regression model. Adjusted ORs with 95\% CIs were calculated after controlling the effect of age and other predictor variables. In all analyses, $P \leq 0.05$ was considered statistically significant.

\section{Research ethics}

We obtained approval from the Research Ethics Committee before starting the study. Informed written consent was obtained from all participating nurses.

\section{Results}

There was no significant difference between the two study groups as regards age $(P=0.968)$ and marital status $(P=0.154)$ (Table 1). Over $90 \%$ of participants in either group showed semi-healthy dietary behaviour, while the rest showed unhealthy behaviour. The difference was not significant $(P$ $=0.790)$. Around $20 \%$ of night shift nurses and $25 \%$ of day shift nurses had been working for $>10$ years, while $45.3 \%$ of night shift nurses and $31.2 \%$ of day shift nurses had been working for 5-10 years. Current smoking was reported by $11.6 \%$ of night shift nurses and by $12.5 \%$ of day shift nurses but the difference was not significant $(P=$ 0.871 ). More than $50 \%$ of either night or day shift nurses did not practice any physical exercise. Among those exercising regularly, $31.4 \%$ of night shift nurses and $26.6 \%$ of day shift nurses reported moderate intensity exercise. The difference between the groups was not significant $(P=0.580)$. It was noted that none of the participants in either group was satisfied with her job. Job dissatisfaction was reported by around $47 \%$ of nurses in each group, while the remaining nurses were indecisive regarding job satisfaction. No significant difference was found between the groups with regard to job satisfaction $(P=0.965)$. Night shift nurses were more prone to obesity (16.3\%) than day shift nurses were (4.7\%). Moreover, night shift nurses were significantly more overweight $(41.9 \%)$ than day shift nurses $(35.9 \%)(P=0.031)$. Night shift nurses had a significantly higher percentage of abnormal serum TG (59.3\%) than day shift nurses had (31.2\%). Also, the proportion of night shift nurses with abnormal LDL was significantly higher than the corresponding proportion among day shift nurses. Similarly, night shift nurses had significantly higher risky HDL level than day shift nurses had.

We investigated the association between abnormal levels of serum TG and the night shift system and other covariates. In univariate analyses, nurses aged $\geq 30$ years, obese, working in the night shift system, and unsatisfied with their job were at higher risk for abnormal serum TGs (Table 2). The other study variables (dietary behaviour, smoking, duration of work, and practice and intensity of physical exercise) were not significantly associated with abnormal TG levels.

Table 3 presents the association between abnormal LDL and night shift work and other covariates. Nurses aged $\geq 40$ years were more prone to higher levels of LDL than those aged $<30$ years. Nurses working in rotatory night shifts had a significantly higher level of abnormal LDL than those working in day shifts. All other study variables (overweight and obesity, smoking, 


\begin{tabular}{|c|c|c|c|}
\hline Points of comparison & $\begin{array}{c}\text { Night shift }(n=86) \\
n(\%)\end{array}$ & $\begin{array}{c}\text { Day shift }(n=64) \\
n(\%)\end{array}$ & $P$ value ${ }^{a}$ \\
\hline $\begin{array}{l}\text { Age groups (yr) } \\
\quad<30 \\
\quad 30-39 \\
\geq 40\end{array}$ & $\begin{array}{l}46(53.5) \\
25(29.1) \\
15(17.4)\end{array}$ & $\begin{array}{l}33(51.6) \\
19(29.7) \\
12(18.7)\end{array}$ & 0.968 \\
\hline $\begin{array}{l}\text { Marital status } \\
\text { Married } \\
\text { Divorced } \\
\text { Widowed } \\
\text { Single }\end{array}$ & $\begin{array}{c}47(54.6) \\
6(7.0) \\
14(16.3) \\
19(22.1)\end{array}$ & $\begin{array}{r}31(48.4) \\
12(18.8) \\
7(10.9) \\
14(21.9)\end{array}$ & 0.154 \\
\hline $\begin{array}{l}\text { Dietary behaviour } \\
\text { Semi-healthy } \\
\text { Unhealthy }\end{array}$ & $\begin{array}{l}79(91.9) \\
7(8.1)\end{array}$ & $\begin{array}{c}58(90.6) \\
6(9.4)\end{array}$ & 0.790 \\
\hline $\begin{array}{l}\text { Working years } \\
\quad<5 \\
5-10 \\
>10\end{array}$ & $\begin{array}{l}28(32.6) \\
39(45.3) \\
19(22.1)\end{array}$ & $\begin{array}{l}27(42.2) \\
20(31.2) \\
17(26.6)\end{array}$ & 0.214 \\
\hline $\begin{array}{l}\text { Smoking } \\
\text { No } \\
\text { Yes }\end{array}$ & $\begin{array}{l}76(88.4) \\
10(11.6)\end{array}$ & $\begin{array}{r}56(87.5) \\
8(12.5)\end{array}$ & 0.871 \\
\hline $\begin{array}{l}\text { Physical exercise intensity } \\
\text { Do not practice/rare } \\
\text { Light } \\
\text { Moderate }\end{array}$ & $\begin{array}{l}49(57.0) \\
10(11.6) \\
27(31.4)\end{array}$ & $\begin{array}{l}36(56.2) \\
11(17.2) \\
17(26.6)\end{array}$ & 0.58 \\
\hline $\begin{array}{l}\text { Job satisfaction } \\
\text { Indecisive } \\
\text { Unsatisfied }\end{array}$ & $\begin{array}{l}46(53.5) \\
40(46.5)\end{array}$ & $\begin{array}{l}34(53.1) \\
30(46.9)\end{array}$ & 0.965 \\
\hline $\begin{array}{l}\text { Weight (BMI) } \\
\text { Normal } \\
\text { Overweight } \\
\text { Obese }\end{array}$ & $\begin{array}{l}36(41.9) \\
36(41.9) \\
14(16.3)\end{array}$ & $\begin{array}{c}38(59.4) \\
23(35.9) \\
3(4.7)\end{array}$ & 0.031 \\
\hline $\begin{array}{l}T G(\mathbf{m g} / \mathbf{d l}) \\
\quad \leq 200 \\
\quad>200\end{array}$ & $\begin{array}{l}35(40.7) \\
51(59.3)\end{array}$ & $\begin{array}{l}44(68.8) \\
20(31.2)\end{array}$ & 0.001 \\
\hline $\begin{array}{l}\text { LDL }(\mathbf{m g} / \boldsymbol{d l}) \\
\quad \leq 130 \\
\quad>130\end{array}$ & $\begin{array}{l}49(57.0) \\
37(43.0)\end{array}$ & $\begin{array}{l}47(73.4) \\
17(26.6)\end{array}$ & 0.038 \\
\hline $\begin{array}{l}H D L(\boldsymbol{m g} / \mathbf{d l}) \\
\quad \geq 40 \\
\quad<40\end{array}$ & $\begin{array}{l}60(69.8) \\
26(30.2)\end{array}$ & $\begin{array}{c}60(93.8) \\
4(6.2)\end{array}$ & $<0.001$ \\
\hline
\end{tabular}

${ }^{a}$ Using $\chi^{2}$ test.

$B M I=$ body mass index $; H L=$ high-density lipoprotein; $L D I=$ low-density lipoprotein; $T G=$ triglyceride.

dietary behaviour, job satisfaction, work duration, and practice and intensity of physical exercise) were not significantly associated with abnormal LDL.

Table 4 reports the association between study variables and low (high risk) levels of HDL. Unhealthy dietary behaviour, night shift working, smoking and working for $>10$ years were significantly associated with low levels of
HDL. The risk of developing low levels of HDL was 4 times higher in those who ate an unhealthy diet, 6.5 times higher in those working in rotatory night shifts, 4 times higher in smokers, and 3.4 times higher those working for $>10$ years.

All the results shown in Tables 2-4 were from univariate analyses and all ORs were considered unadjusted and crude. Therefore, we applied 3 models of binary logistic regression; one for each type of lipid profile (TG, LDL and HDL). In each model we used the stepwise forward method to adjust for all variables that were significantly associated with lipid profile in the bivariate analysis. As shown in Table 5, the predictors for abnormal levels of TG were nurses' age $30-39$ or $\geq 40$ years and working in the night shift system. 


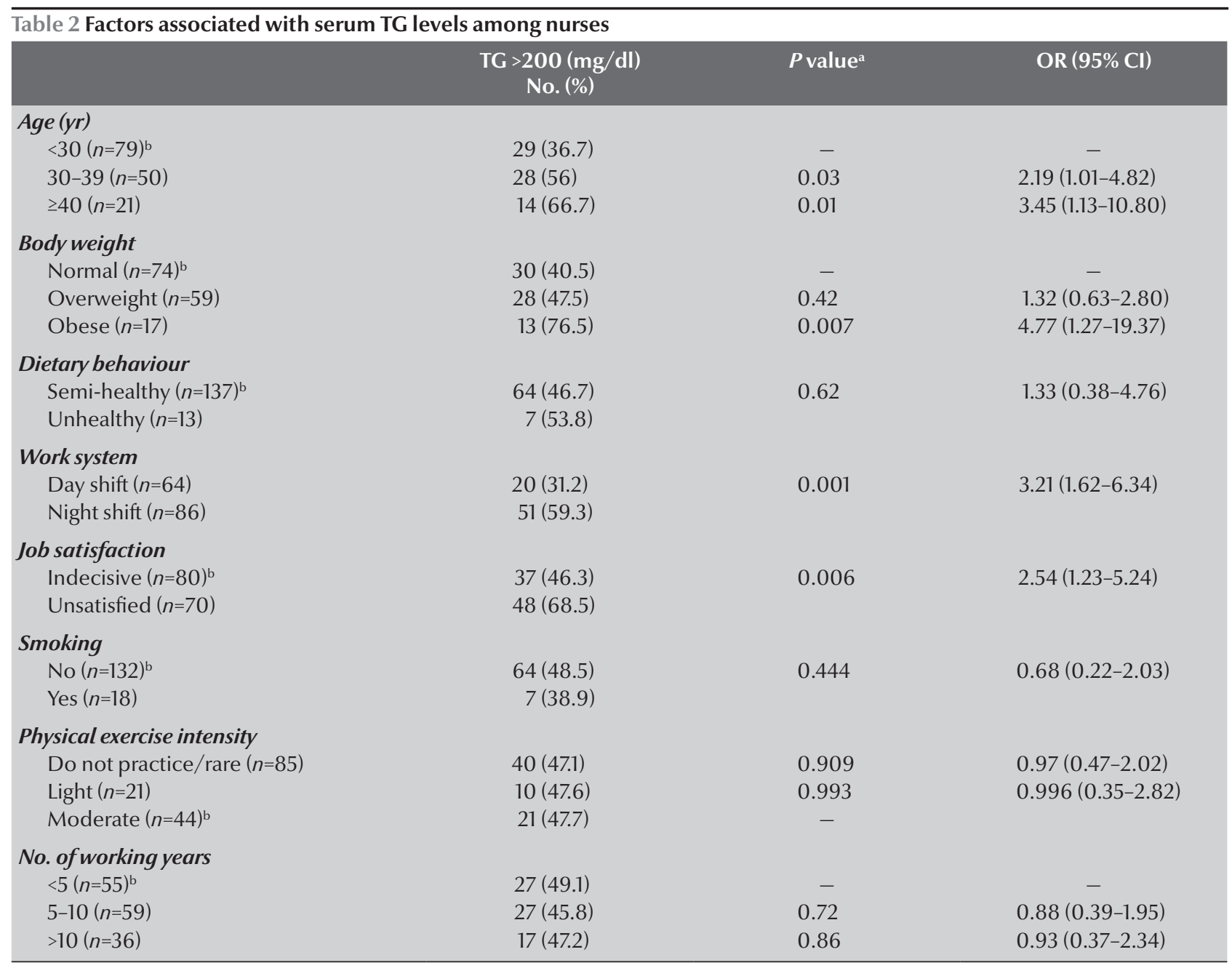

${ }^{a} U$ sing $\chi^{2}$ test.

${ }^{b}$ Reference group.

$C l=$ confidence interval; $O R=$ odds ratio; $T G=$ triglyceride .

For abnormal level of LDL, the only predictor was nurses' age $\geq 40$ years. For low (high risk) HDL level, the predictors were unhealthy diet, working in the night shift system and tobacco smoking.

\section{Discussion}

The current study showed that the percentage of obese and overweight nurses was significantly higher among night shift than day shift workers. This was similar to the results of Saberi and Moraweji (9) who showed that obesity was more frequent among night than day shift nurses in the Islamic Republic of Iran. Irregular meal consumption is one of the factors leading to obesity and this was found to be significantly higher among night shift than day shift workers (9). Our findings also support those of another study in which both current and cumulative night shifts were associated with obesity (10). The current study showed that $56.7 \%$ of the nurses did not or only rarely performed physical activity. This confirms the findings of Naidoo et al, who reported poor physical activity levels among nurses in South Africa (11). These findings are supported by other studies that found that nurses do not meet the recommended levels of physical activity required for health benefit (12).

Our study showed that the majority of participants ate semi-healthy food; some ate unhealthy food such as processed meat, sweets, caffeinated beverages, and meat or poultry with skin; and others ate healthy food like fruit and vegetables. This variability in eating habits was also shown in another study in which $66.3 \%$ of nurses had a moderately healthy diet, $16.7 \%$ had a mostly healthy diet and $17 \%$ had an unhealthy diet (13).

It is evident that our nurses were overweight/obese, had a poor level of physical activity and mainly ate semihealthy food. This agrees with other researchers who have reported a high percentage of health-related conditions and risk factors such as obesity, overweight, physical inactivity and poor eating habits among shift and rotational night shift workers $(14,15)$. 


\begin{tabular}{|c|c|c|c|}
\hline & $\begin{array}{c}\mathrm{LDL}>130 \\
(\mathrm{mg} / \mathrm{dl}) \\
n(\%)\end{array}$ & $P$ value $^{\mathrm{a}}$ & OR $(95 \% \mathrm{Cl})$ \\
\hline \multicolumn{4}{|l|}{ Age (yr) } \\
\hline$<30(n=79)^{\mathrm{b}}$ & $22(27.8)$ & - & - \\
\hline $30-39(n=50)$ & $19(38)$ & 0.22 & $1.59(0.70-3.61)$ \\
\hline$\geq 40(n=21)$ & $13(61.9)$ & 0.003 & $4.21(1.39-13.07)$ \\
\hline \multicolumn{4}{|l|}{ Body weight } \\
\hline Normal $(n=74)^{\mathrm{b}}$ & $22(29.7)$ & - & - \\
\hline Overweight ( $n=59)$ & $26(44.1)$ & 0.088 & $1.86(0.86-4.06)$ \\
\hline Obese $(n=17)$ & $6(35.3)$ & 0.65 & $1.29(0.37-4.42)$ \\
\hline \multicolumn{4}{|l|}{ Dietary Behaviour } \\
\hline Semi-healthy $(n=137)^{\mathrm{b}}$ & $49(35.8)$ & 0.84 & $1.12(0.30-4.07)$ \\
\hline Unhealthy $(n=13)$ & $5(38.5)$ & & \\
\hline \multicolumn{4}{|l|}{ Work system } \\
\hline Day shift $(n=64)$ & $17(26.6)$ & 0.038 & $2.08(1.04-4.20)$ \\
\hline Night shift $(n=86)$ & $37(43)$ & & \\
\hline \multicolumn{4}{|l|}{ Job satisfaction } \\
\hline Indecisive $(n=80)^{\mathrm{b}}$ & $28(35.0)$ & 0.78 & $1.10(0.53-2.26)$ \\
\hline Unsatisfied ( $n=70)$ & $26(37.1)$ & & \\
\hline \multicolumn{4}{|l|}{ Smoking } \\
\hline No $(n=132)^{\mathrm{b}}$ & $48(36.4)$ & 0.835 & $0.90(0.28-2.79)$ \\
\hline Yes $(n=18)$ & $6(33.3)$ & & \\
\hline \multicolumn{4}{|l|}{ Physical exercise intensity } \\
\hline Do not practice/rare $(n=85)$ & $33(38.8)$ & 0.55 & $1.36(0.63-2.94)$ \\
\hline Light $(n=21)$ & 7 (33.3) & 0.87 & $1.07(0.35-3.24)$ \\
\hline Moderate $(n=44)^{\mathrm{b}}$ & $14(31.8)$ & - & - \\
\hline \multicolumn{4}{|l|}{ No. of working years } \\
\hline$<5(n=55)^{\mathrm{b}}$ & $19(34.5)$ & - & - \\
\hline $5-10$ years $(n=59)$ & $16(27.1)$ & 0.39 & $0.71(0.29-1.69)$ \\
\hline$>10(n=36)$ & $19(52.8)$ & 0.08 & $2.12(0.82-5.48)$ \\
\hline
\end{tabular}

${ }^{a} U$ sing $\times 2$ test.

${ }^{b}$ Reference group.

$C l=$ confidence interval; $L D L=$ low-density lipoprotein; $O R=$ odds ratio.

In the current study, some of the senior nurses were working as nurse supervisors. This may have led to an increase in their sedentary routine work and decreased energy expenditure, which in turn increased the risk of becoming overweight or obese. Longer service, associated with eating an unhealthy diet, leads to overweight and obesity (16). This information may explain the significant association between age and elevated levels of serum TG and LDL in our study. It also explains the significant association between length of service and low (high risk) levels of HDL.

In our study, job satisfaction was only associated with high levels of TGs but after adjustment for other confounding variables such as age, this after adjustment, only age $\geq 40$ years was included in the model. For HDL, The crude analysis showed that unhealthy dietary behaviour, night shift, smoking and working for $>10$ years were significantly associated with low (high risk) levels of HDL. After adjustment for age and other potential factors, unhealthy diet, night shift and smoking were still significantly associated with low levels of HDL. Similar studies have reported that nurses working night shifts have increased risk of obesity, with low HDLcholesterol and high TG (18). Another study has shown that years of exposure to night shifts were correlated significantly with body mass index, which was in turn correlated with increased TG (19). Evidence also suggests that blood lipids are affected by nutrition and body weight (20).

The findings that night shift nurses had significantly higher levels of LDL and total cholesterol and a higher risk of heart disease (i.e., lower levels of HDL) agree with a previous study that found that high levels of total cholesterol and TGs were significantly more prevalent among night than day shift workers, but there was no difference in the percentage of HDL and TG between night and day workers (21). Other studies have shown that there was no difference in serum LDL levels between night and day shift workers (22,23). A cross-sectional study on 319 Italian workers showed no significant difference in HDL between day and night shift workers (24). However, other studies have shown that low HDL serum level was more prevalent in night than day shift workers (25).

Low HDL level and smoking are known risk factors for coronary heart disease. In our study, tobacco smoking was significantly associated with low HDL levels. This agrees with the findings of a study in which smokers had significantly lower mean HDL level than nonsmokers (26). Another study concluded that cigarette smoking also appears to disrupt lipid and lipoprotein metabolism, leading to elevated plasma 


\begin{tabular}{|c|c|c|c|}
\hline & $\begin{array}{l}\text { Low (high risk) } \\
\text { HDL levels } \\
n(\%)\end{array}$ & $P$ value $^{\mathrm{a}}$ & OR $(95 \% \mathrm{Cl})$ \\
\hline $\begin{array}{l}\text { Age }(y r) \\
\qquad 30(n=79)^{\mathrm{b}} \\
\quad 30-39(n=50) \\
\quad \geq 40(n=21)\end{array}$ & $\begin{aligned} 16 & (20.3) \\
7 & (14) \\
7 & (33.3)\end{aligned}$ & $\begin{array}{l}- \\
0.36 \\
0.20\end{array}$ & $\begin{array}{c}- \\
0.64(0.22-1.84) \\
1.47(0.60-6.39)\end{array}$ \\
\hline $\begin{array}{l}\text { Weight } \\
\text { Normal }(n=74)^{\mathrm{b}} \\
\text { Overweight }(n=59) \\
\text { Obese }(n=17)\end{array}$ & $\begin{array}{c}16(21.6) \\
11(18.6) \\
3(17.6)\end{array}$ & $\begin{array}{l}- \\
0.67 \\
0.71\end{array}$ & $\begin{array}{c}- \\
0.83(0.32-2.12) \\
0.78(0.16-3.43)\end{array}$ \\
\hline $\begin{array}{l}\text { Dietary behaviour } \\
\text { Semi-healthy }(n=137)^{\mathrm{b}} \\
\text { Unhealthy }(n=13)\end{array}$ & $\begin{array}{l}24(17.5) \\
6(46.2)\end{array}$ & 0.01 & $4.04(1.08-15.02)$ \\
\hline $\begin{array}{l}\text { Work pattern } \\
\text { Day shift }(n=64) \\
\text { Night shift }(n=86)\end{array}$ & $\begin{array}{c}4(6.2) \\
26(30.2)\end{array}$ & $<0.001$ & $6.50(2.14-19.76)$ \\
\hline $\begin{array}{l}\text { Job satisfaction } \\
\text { Indecisive }(n=80)^{\mathrm{b}} \\
\quad \text { Unsatisfied }(n=70)\end{array}$ & $\begin{array}{l}15 \text { (18.8) } \\
15(21.4)\end{array}$ & 0.68 & $1.18(0.49-2.83)$ \\
\hline $\begin{array}{l}\text { Smoking } \\
\text { No }(n=132)^{\mathrm{b}} \\
\text { Yes }(n=18)\end{array}$ & $\begin{array}{r}22(16.7) \\
8(44.4)\end{array}$ & 0.006 & $4.00(1.42-11.28)$ \\
\hline $\begin{array}{l}\text { Physical exercise intensity } \\
\text { Do not practice/rare }(n=85) \\
\text { Light }(n=21) \\
\text { Moderate }(n=44)^{\mathrm{b}}\end{array}$ & $\begin{array}{l}22(25.9) \\
1(4.8) \\
7(15.9)\end{array}$ & $\begin{array}{l}0.287 \\
0.381\end{array}$ & $\begin{array}{c}1.85(0.72-4.74) \\
0.26(0.03-2.30)\end{array}$ \\
\hline $\begin{array}{l}\text { No. of working years } \\
<5(n=55)^{\mathrm{b}} \\
\quad 5-10(n=59) \\
\quad>10(n=36)\end{array}$ & $\begin{array}{r}7(12.7) \\
11(18.6) \\
12(33.3)\end{array}$ & $\begin{array}{l}- \\
0.543 \\
0.036\end{array}$ & $\begin{array}{c}- \\
1.57(0.56-4.04) \\
3.43(1.20-9.83)\end{array}$ \\
\hline
\end{tabular}

${ }^{a}$ Using $\times 2$ test.

${ }^{b}$ Reference group.

$C l=$ confidence interval; $L D L=$ low-density lipoprotein; $O R=$ odds ratio.

cholesterol, TGs and LDL-cholesterol, and lower HDL-cholesterol levels as compared to nonsmokers (27).

Our study had some limitations. The sample size for day shift nurses was less than the calculated one, which was due to the exclusion of nurses who had recently joined the day shift system after many years of working rotatory night shifts. Also, there was recall bias that arose from self-reporting of lifestyle behaviour, for example, dietary behaviour and physical exercise.

In conclusion, nurses working in rotatory night shifts have a higher risk of abnormal lipid profile. All nurses were dissatisfied with their job and the percentage of smoking was high among the study groups. Hospital strategies for lifestyle interventions should include meal boxes with a healthy diet, offered at a reasonable price to all healthcare providers, and providing information via newsletters/posters about physical exercise, hazards of smoking and healthy diet. Smoking-free zones must be implemented in hospitals.

\section{Funding: None}

Competing interests: None declared

\begin{tabular}{|c|c|c|}
\hline Lipid profile & Predictors & Adjusted OR (95\% Cl) \\
\hline TG >200 (mg/dl) & $\begin{array}{l}\text { Age } 30-39 \text { yr } \\
\text { Age } \geq 40 \mathrm{yr} \\
\text { Night shift }\end{array}$ & $\begin{array}{l}2.63(1.22-5.68) \\
3.23(1.12-9.29) \\
3.47(1.69-7.10)\end{array}$ \\
\hline LDL >130 (mg/dl) & Age $\geq 40 \mathrm{yr}$ & $4.21(1.54-11.55)$ \\
\hline $\mathrm{HDL}<40(\mathrm{mg} / \mathrm{dl})$ & $\begin{array}{l}\text { Unhealthy diet } \\
\text { Night shift } \\
\text { Smoking }\end{array}$ & $\begin{array}{l}4.06(1.03-16.08) \\
8.76(2.56-30.02) \\
4.16(1.25-13.87)\end{array}$ \\
\hline
\end{tabular}

$C I=$ confidence interval; $H D L=$ high-density lipoprotein $L D L=$ low-density lipoprotein $T G$ =triglyceride . 


\section{References}

1. Sudo N, Ohtsuka R. Nutrient intake among female shift workers in a computer factory in Japan. Int J Food Sci Nutr. 2001 Jul;52(4):367-78. PMID:11474902

2. Wong $\mathrm{H}$, Wong MC, Wong SY, Lee $\mathrm{A}$. The association between shift duty and abnormal eating behavior among nurses working in a major hospital: a cross-sectional study. Int J Nurs Stud. 2010 Aug;47(8):1021-7. PMID:20116059

3. Morikawa Y, Miura K, Sasaki S, Yoshita K, Yoneyama S, Sakurai $\mathrm{M}$, et al. Evaluation of the effects of shift work on nutrient intake: a cross-sectional study. J Occup Health. 2008;50(3):2708. PMID:18408349

4. Fuller TP, Bain El. Health and safety: shift workers give sleep short shrift. Am J Nurs. 2010 Feb;110(2):28-30. PMID:20107397

5. Kroenke CH, Spiegelman D, Manson J, Schernhammer ES, Colditz GA, Kawachi I. Work characteristics and incidence of type 2 diabetes in women. Am J Epidemiol. 2007 Jan 15;165(2):175-83. PMID:17071844

6. Apostolopoulos Y, Sonmez S, Shattell MM, Belzer M. Work site induced morbidities among truck drivers in the United States. AAOHN. 2010 Jul;58(7):285-96. PMID:20608567

7. Parikh P, Taukari A, Bhattacharya T. Occupational stress and coping among nurses. J Health Manag. 2004;6(2):115-27.

8. Spector PE. Measurement of human service staff satisfaction development of the Job Satisfactory Survey. Am J Community Psychol. 1985 Dec;13(6):693-713. PMID:4083275

9. Saberi HR, Moraweji AR. Gastrointestinal complaints in shift working and day working nurses in Iran. J Circadian Rhythms. 2010 Oct 7;8:9. PMID:20929565

10. Peplonska B, Bukowska A, Sobala W. Association of rotating night shift work with body mass index and abdominal obesity among nurses and midwives. PLoS One. 2015 Jul 21;10(7):e0133761. PMID:26196859

11. Naidoo R, Coopoo Y. The health and fitness profiles of nurses in Kwazulu-Natal. Curationis. 2007 Jun;30(2):66-73. PMID: 17703824

12. Blake $\mathrm{H}$, Harrison $\mathrm{C}$. Health behaviors and attitudes towards being role models. Br J Nurs 2013 Jan 24-Feb 13; 22(2):86-94). PMID:23587891

13. Albert NM, Butler R, Sorrell J. Factors related to healthy diet and physical activity in hospital based clinical nurses. Online J Issues Nurs 2014 Sep 30;19(3):5. PMID:26824153

14. De Bacquer D, Van Risseghem M, Clays E, Kittel F, De Backer G, Braeckman L. Rotating shift work and the metabolic syndrome: a prospective study. Int J Epidemiol. 2009 Jun;38(3):848-54. PMID:19129266

15. Zhao I, Bogossian F, Song S, Turner C. The association between shift work and unhealthy weight: a cross-sectional analysis from the nurses and mid wives e-cohort study. J Occup Environ Med. 2011 Feb;53(2):153-8. PMID:21270661

16. Ayree PA, Helegbe GK, Baah J, Sarfo-Asante RA, Quist-Therson R. Prevalence and risk factors for overweight and obesity among nurses in Tamale Metropolis of Ghana. J Med Biomed Sci. 2013;2(4):13-23 (http://dx.doi.org/10.4314/jmbs.v2i4.3).

17. Evolahti A, Hultcrantz M, Collins A. Psychosocial work environment and lifestyle as related to lipid profiles in perimenopausal women. Climacteric. 2009 Apr;12(2):131-45. PMID:19085562

18. Karlsson B, Knutsson A, Lindahl B. Is there an association between shift work and having a metabolic syndrome? Results from a population based study of 27485 people. Occup Environ Med. 2001 Nov;58(11):747-52. PMID:11600731

19. Parkes KR. Shift work and age as interactive predictors of body mass index among offshore workers. Scand J Work Environ Health. 2002 Feb;28(1):64-7. PMID:11871855

20. Report of the National Cholesterol Education Program Expert Panel on Detection, Evaluation, and Treatment of High Blood Cholesterol in Adults. The Expert Panel. Arch Intern Med. 1998 Jan;148(1):36-69. PMID:3422148

21. Ghiasvand M, Heshmat R, Golpira R, Haghpanah V, Soleimani A, Shoushtarizadeh P, et al. Shift working and risk of lipid disorders: a cross-sectional study. Lipids Health Dis. 2006 Apr 10;5:9. PMID:16606444

22. Knutsson A. Relationship between serum triglycerides and gamma glutamytransferose among shift and day workers. J Intern Med. 1989 Nov;226(5):337-9. PMID:2572667

23. Knutsson A, Akerstedt T, Jonsson BG. Prevalence of risk factors for coronary artery disease among day and shift workers. Scand J Work Environ Health. 1988 Oct;14(5):317-21. PMID:3201192

24. Di Lorenzo L, De Pergola G, Zocchetti C, L'Abbate N, Basso A, Pannacciulli N, et al. Effect of shift work on body mass index: results of a study performed in 319 glucose tolerant men working in a Southern Italy industry. Int J Obes Relat Metab Disord. 2003 Nov;27(11):1353-8. PMID:14574346

25. Frasson El, Alfredsson LS. de faire UH, Knutsson A, Westerholm PJ. Leisure time, occupational and household physical activity and risk factors for cardiovascular disease in working men and women: the Wolf Study. Scand J Public Health. 2003:31(5):324-33. PMID:14555368

26. Batic-Mujanovic. Zildzic M, Beganlic A, Kusljugic Z. [The effect of cigarette smoking on HDL-cholesterol level]. Med Arh. 2006;60(6 Suppl 2):90-2 (in Bosnian). PMID: 18172992

27. He BM, Zhao SP, Peng ZY. Effects of cigarette smoking on HDL quantity and function: implications for atherosclerosis. J Cell Biochem. 2013 Nov;114(11):2431-6. PMID: 23852759 